\title{
PENGARUH MODELPEMBELAJARAN INKUIRI TERHADAP KEMAMPUAN MENEMUKAN UNSUR KEBAHASAAN TEKS CERITA FABEL OLEH SISWA KELAS VIII SMP NEGERI 3 BINJAI
}

\author{
Zira Fatmaira \\ Jurusan Pendidikan Bahasa dan Sastra Indonesia \\ PPS Universitas Negeri Medan \\ Zirafatmaira0301@gmail.com
}

\begin{abstract}
Abstrak .Penelitian ini bertujuan untuk mengetahui pengaruh Model Pembelajaran Inkuiri terhadap Kemampuan Menemukan Unsur kebahasaan Teks Cerita Fabel Oleh Siswa Kelas VIII SMP Negeri 3 Binjai. Lokasi penelitian ini dilaksanakan di SMP Negeri 3 Binjai dengan populasi 364 orang, yakni kelas VIII-1 berjumlah36 siswa, VIII-2 berjumlah39 siswa, VIII-3 Berjumlah 43 siswa, VIII-4 berjumlah 44 siswa, VIII-5 berjumlah 43, VIII-6 berjumlah 42 siswa, VIII-7 berjumlah 40 siswa, VIII-8 berjumlah 40 siswa, dan VIII-9 berjumlah 40 siswa.Dalam penelitian ini, dilakukan pengambilan sampel dengan cara random kelas. Kelas VIII-1 diterapkan sebagai kelas eksperimen yaitu kelas yang menerima pembelajaran dengan menggunakan Model Pembelajaran Inkuiri. Kelas VIII-7 diterapkan sebagai kelas kontrol yaitu kelas yang menerima pembelajaran dengan menggunakan model konvensional. Metode yang digunakan dalam penelitian ini adalah metode eksperimen. model pembelajaran yang digunakan model pembelajaran inkuiri dan model konvensional,dan uji hipotesis atau uji . Instrument yang digunakan dalam peneltian ini adalah tes esai. Hasil penelitian dapat diketahui bahwa kemampuan menemukan unsur kebahasaan teks cerita fabel pada kelas eksperimen paling banyak berada pada nilai 66-67 yaitu 55,65\% artinya kemampuan dari sebagian besar siswa kelas eksperimen berada pada tingkat sedang. Pada kelas kontrol kemampuan menemukan unsur kebahasaan teks cerita fabel paling banyak berada pada nilai 26-36 yaitu 50\% artinya kemampuan menemukan unsur kebahasaan teks cerita fabel pada tingkat kurang. Hasil yang didapat pada penelitian ini adalah dengan uji normalitas pada model inkuiri dan model konvensional adalah normal.Untuk uji homogenitas $F_{\text {hitung }}>F_{\text {tabel }}$ 1,74> 1,72. Dan untuk pengujian hipotesis $n=76$ dengan $d k=(N 1+N 2)-2=74$ diperoleh nilai $t_{\text {tabel }}=1,666$ sehingga $t_{\text {hitung }}>t_{\text {tabel }}$ yaitu $14,77>1,666$ maka $H_{0}$ ditolak dan Ha diterima. Ini berarti bahwa Hipotesis Alternatif (Ha) yang menyatakan bahwa "Ada pengaruh model pembelajaran Inkuiri terhadap kemampuan menemukan unsur kebahasaan teks cerita fabel oleh siswa kelas VIII SMP Negeri 3 Binjai."
\end{abstract}

Kata kunci : Model Pembelajaran Inkuiri, Kemampuan Menemukan Unsur Kebahasaan Teks Cerita Fabel 


\section{PENDAHULUAN}

Mata pelajaran bahasa Indonesia adalah salah satu kunci kelulusan dalam pembelajaran disekolah, siswa harus mampu menguasai mata pelajaran bahasa Indonesia yang diajarkan oleh guru. Dalam pembelajaran bahasa Indonesia tidak terlepas dari unsur kebahasaan gramatik yaitu morfologi dan sintaksis, siswa harus mampu menguasai unsur kebahasaan tersebut. Faktanya banyak anak yang mengalami kesulitan dalam mempelajari atau menemukan unsur kebahasaan khususnya dalam kata kerja, setiap anak memiliki kemampuan yang berbeda-beda ada yang memiliki rasa ingin tahu yang tinggi dan ada juga yang tidak mau tahu sama sekali. Banyak penyebab anak sulit dalam menemukan unsur kebahasaan karena berbagai faktor, salah satunya yaitu model pembelajaran yang dilakukan oleh guru kurang tepat dalam materi pembelajaran.

Berdasarkan masalah yang sering peneliti temukan dalam pembelajaran yaitu kurangnya pemahaman siswa dalam menemukan unsur kebahasaan, terutama pada kata kerja sehingga siswa mengalami kesulitan saat menemukan unsur kebahasaan suatu teks cerita fabel karena kurangnya pemahaman tersebut mengakibatkan nilai ketuntasan belajar dibawah rata-rata dengan jumlah nilai 60 dari hasil penugasan yang diberikan pada saat proses pembelajaran. Berdasarkan permasalahan tersebut perlu dilakukan pemecahan masalah yaitu guru harus memiliki keahlian untuk menciptakan dan memilki variasi model dan strategi dalam mengajar. Dalam hal ini guru merupakan sarana penghubung yang menanamkan metode atau model yang tepat dan sederhana agar siswa dapat menggali potensi yang ada dalam dirinya juga untuk menggali ilmu pengetahuan sesuai dengan karakter dan kebutuhannya. Agar siswa dapat menjadi lebih aktif lagi saat proses pembelajaran guru harus memiliki model pembelajaran yang bervariasi agar siswa tidak jenuh dalam proses belajar mengajar (PBM).

Berdasarkan uraian di atas, untuk memicu kemampuan siswa dalam menemukan unsur kebahasaan teks cerita fabel, peneliti tertarik untuk membuat judul penelitian. "Pengaruh Model Pembelajaran Inkuiri terhadap Kemampuan Menemukan Unsur Kebahasaan Teks Cerita Fabel Oleh Siswa Kelas VIII SMP Negeri 3 Binjai”. Dengan model pembelajaran inkuiri diharapkan siswa dapat mampu menemukan unsur 
kebahasaan teks cerita fabel dan Model Konvensional adalah metode perbandingan yang sering dilakukan dalam proses pembelajaran yang dilakukan oleh guru. Inkuiri adalah suatu proses untuk memperoleh dan mendapatkan informasi dengan melalukan observasi dan eksperimen untuk mencari jawaban atau memecahkan masalah terhadap pertanyaan atau masalah dengan mengembangkan kemampuan berfikir kritis dan logis. Model pembelajaran inkuri merupakan salah satu model yang mendorong siswa untuk aktif dalam pembelajaran. Hal ini merupakan pendapat bahwa: "Pembelajaran inkuiri adalah kegiatan pembelajaran dimana siswa didorong untuk belajar melalui keterlibatan aktif mereka sendiri dengan konsep - konsep dan prinsip - prinsip, dan guru mendorong siswa untuk memiliki pengalaman dan melalukan percobaan yang memungkinkan siswa menemukan prinsip-prinsip untuk diri mereka sendiri”. Kunandar (dalam Aris Shoimin 2014: 85)

Wina (dalam Aris Shoimin2014: 85) mengatakan, "Bahwa strategi pembelajaran Inkuiri adalah rangkaian kegiatan pembelajaran yang menekankan pada prosesberfikir secara kritis dan analitis untuk mencari dan menemukan sendri jawaban suatu masalah yang di pertanyakan". Inkuiri (inquiry) adalah proses berfikir untuk memahami tentang sesuatu dengan mengajukan pertanyaan. Inkuiri dapat dijadikan sebagai pendekatan pembelajaran, strategi pembelajaran, atau metode pembelajaran. Metode inkuiri menekankan pada proses penyelidikan berbasis pada upaya menjawab pertanyaan. Inkuiri adalah investigasi tentang ide, pertanyaan, atau permasalahan. Pembelajaran berbasis inkuiri mencakup proses mengajukan permasalahan, memperoleh informasi, berfikir kreatif tentang kemungkinan penyelesaian masalah, membuat keputusan, dan membuat kesimpulan.

Berdasarkan pendapat di atas inkuiri adalah metode pembelajaran yang menekankan siswa untuk lebih aktif dan siswa yang melakukan penyelidikan atau observasi, siswa yang menemukan jawaban mempelajari pertanyaanpertanyaan yang ada dan guru sebagai fasilitator hanya mengarahkan proses pembelajaran tersebut. Pembelajaran bahasa indonesia berbasis teks dilaksanakan dengan menerapkan prinsip bahwa(1) bahasa hendaknya dipandang sebagai teks, bukan semata-mata kumpulan kata-kata atau kaidah-kaidah kebahasaan, (2) penggunaan bahasa merupakan proses pemilihan bentukbentuk kebahasaan untuk mengungkapkan makna,(3) bahasa bersifat fungsional yaitu penggunaan bahasa yang tidak pernah dapat dilepaskan dari konteks karena 
dalam bentuk bahasa yang digunakan itu tercermin ide, sikap, nilai,dan ideologi penggunanya, dan (4) bahasa merupakan sarana pembentukan kemampuan berfikir manusia.

Fakta menunjukkan bahwa manusia hidup dalam dunia kata-kata. Kata-kata di rangkai untuk mengkomunikasikan gagasan / makna, sebenarnya kita telah menciptakan teks. Ketika kita mengekspresikan gagasan secara lisan (berbicara) atau secara tulis (menulis) berarti kita telah menciptakan teks. Dapat disimpulkan bahwa teks adalah ujaran (lisan) atau tulis bermakna yang berfungsi untuk mengekspresikan gagasan. Teks adalah a. naskah yang berupa katakata dari pengarang; b.kutipan dari kitab suci untuk pangkal ajaran atau alasan, c. Bahan tertulis untuk dasar memberikan pelajaran, berpidato, dan sebagainya. Jenis- jenis teks dapat diperinci daalam berbagai jenis, seperti deskripsi, penceritaan (recount), prosedur, laporan, eksplamasi, eksposisi, diskusi, surat, iklan, catatan harian, negoisasi, pantun, dogeng, anekdot, dan fiksi sejarah. Semua jenis teks itu dapat dikelompokkan ke dalam teks cerita, teks faktual dan teks tanggapan.

Dua kelompok yang disebutkan terakhir itu merupakan teks nonsastra yang masing-masing dapat dibagi lebih lanjut menjadi teks laporan dan teks prosedural serta teks transaksional dan teks ekspositori. Sementara itu, teks cerita merupakan jenis teks sastra yang dapat diperinci menjadi teks cerita naratif dan teks cerita nonnaratif. Jenis-jenis teks itu dapat dibedakan atas dasar tujuan yang tidak lain adalah fungsi sosial teks, struktur teks, dan ciri-ciri kebahasaan teks tersebut.

Priyatni (2014: 66). Mengatakan, “Teks dapat dikelompokkan menjadi dua kategori besar (genre), yaitu ganre sastra dan genre faktual. Genre sastra bertujuan untuk mengajak emosi dan imajinasi pembaca/penyimak. Genre sastra membuat pembaca/penyimak, tertawa, menangis, dan merefleksi diri/menyucikan diri (kartasis). Genre sastra dapat dikelompokkan menjadi tiga jenis yaitu teks naratif (cerpen,novel), puitik dan dramatik". Teks naratif bertujuan menceritakan sesuatu, teks puitis bertujuan untuk mengekspresikan perasaa atau kesan terhadap sesuatu, dan teks dramatik bertujuan mengkomunikasikan ide atau pengalaman melalui aksi panggung. Ketiga jenis teks dapat berbentuk lisan atau tulisan. Secara etimologis fabel berasal dari bahas latin fabulat. Cerita fabel merupakan cerita tentang kehidupan binatang yang berperilaku menyerupai manusia. Fabel termasuk jenis cerita fiksi, bukan kisah tentang kehidupan nyata. Cerita fabel sering juga disebut cerita 
moral karena pesan yang ada di dalam cerita fabel berkaitan erat dengan moral.

Teks cerita fabel tidak hanya mengisahkan kehidupan binatang, tetapi juga mengisahkan kehidupan manusia dengan segala karakternya. Binatangbinatang yang ada pada cerita fabel memiliki karakter seperti manusia.

Karakter mereka ada yang baik dan ada juga yang tidak baik. Mereka mempunyai sifat jujur, sopan, pintar, dan senang bersahabat, serta melakukan sifat terpuji. Mereka ada juga yang berkarakter licik, culas, sombong, suka menipu dan ingin menang sendiri.

Cerita fabel tidak hanya ditunjukkan kepada anak-anak, tetapi juga kepada orang dewasa. Cerita fabel menjadi salah satu sarana yang potensial dalam menanamkan nilai-nilai moral. Fabel ialah cerita binatang yang mengandung pendidikan moral. Binatang diceritakan mempunyai akal, tingkah laku, dan dapat berbicara seperti manusia. Struktur teks cerita fabel antara lain :

a. Orientasi (pengenalan tokoh, tempat, waktu dan sebagainya) peninjauan untuk menentukan sikap (arah, tempat, dan sebagainya) yang tepat dan benar; pandangan yang mendasari pikiran, perhatian atau kecendrungan. b. Komplikasi (masalah yang terjadi dan terdapat di dalam sebuah teks cerita fabel).

c. Resolusi (penyelesaian masalah dari sebuah teks cerita fabel)

d. Koda (akhir cerita dan perubahan yang terjadi pada tokoh dan atau pelajaran yang dapat dipetik dari cerita, sifatnya opsional).

Rumusan masalah pada penelitian ini adalah: 1. Bagaimanakah kemampuan siswa dalam menemukan unsur kebahasaan teks cerita fabel dengan menggunakan model pembelajaran inkuiri oleh siswa kelas VIII SMP Negeri 3 Binjai? 2. Bagaimanakah kemampuan siswa dalam menemukan unsur kebahasaan teks cerita fabel dengan menggunakan modelkonvensional oleh siswa kelas VIII SMP Negeri 3 Binjai? 3. Apakah ada pengaruh model pembelajaran inkuri terhadap kemampuan menemukan unsur kebahasaan teks cerita fabel oleh siswa kelas VIII SMP Negeri 3 Binjai? Berdasarkan rumusan masalah tersebut, tujuan dalam penelitian ini adalah: 1 . Untuk mengetahui kemampuan siswa dalam menemukan unsur kebahasaan teks cerita fabel dengan menggunakan model pembelajaran inkuiri oleh siswa Kelas VIII SMP Negeri 3 Binjai. 2. Untuk mengetahui kemampuan siswa dalam menemukan unsur kebahasaan teks cerita fabel dengan menggunakan model 
konvensional oleh siswa Kelas VIII SMP

Negeri 3 Binjai. 3. Untuk mengetahui pengaruh model pembelajaran inkuri terhadap kemampuan menemukan unsur kebahasaan teks cerita fabel oleh siswa kelas VIII SMP Negeri 3 Binjai.

\section{METODE PENELITIAN}

Penelitian ini berbentuk penelitian eksperimen. Menurut Sukmadinata (2010: 52)"Metode penelitian merupakan rangkaian cara atau kegiatan pelaksanaan penelitian yang didasari oleh asumsiasumsi dasar, pandangan-pandangan filosofis dan ideologis, pertanyan dan isuisu yang dihadapi". Tujuan penelitian ini adalah untuk mengetahui pengaruh model pembelajaran Inkuiri terhadap kemampuan menemukan unsur kebahasaan teks cerita fabel. Berhasil tidaknya suatu penelitian, sangat ditentukan oleh metode yang digunakan.

Sesuai dengan masalah dan tujuan penelitian,maka digunakan metode eksperimen. Menurut Sugiyono (2010: 107) "Metode penelitian eksperimen dapat diartikan sebagai metode penelitian yang digunakan untuk mencari pengaruh perlakuan tertentu terhadap yang lain dalam kondisi yang terkendali”.

Lebih jelasnya desain penelitian yang digunakan dapat dilihat sebagai berikut:

Tabel 1.

Desain Penelitian Posttes- Only Control Desain

\begin{tabular}{|c|c|c|c|c|}
\hline No & Jurusan & Kelompok & $\begin{array}{c}\text { Perlakuan } \\
\text { (Treatment) }\end{array}$ & Posttest \\
\hline 1 & VIII-1 & $\mathrm{R}$ & $\mathrm{X}$ & $\mathrm{O}_{2}$ \\
\hline 2 & VIII-7 & $\mathrm{R}$ & & $\mathrm{O}_{4}$ \\
\hline
\end{tabular}

Keterangan:

R : Kelas Eksperimen

R : Kelas Kontrol

X :Perlakuan dengan model Inkuiri

$\mathrm{O}_{2} \quad$ : Posttest kemampuan menemukan unsur kebahasaan teks cerita fabel kelompok eksperimen

$\mathrm{O}_{4} \quad$ : Posttest kemampuan menemukan unsur kebahasaan teks cerita fabel kelompok kontrol. 
Berikut ini akan dijelaskan langkah- langkah pembelajaran kelas eksperimen dan kelas kontrol dalam kemampuan menemukan unsur kebahasaan teks cerita fabel:

Tabel 2.

Langkah-langkah Pembelajaran Kelas Eksperimen dan Kelas Kontrol

\begin{tabular}{|c|c|c|c|}
\hline Waktu & Eksperimen & Waktu & Kontrol \\
\hline 10 Menit & $\begin{array}{l}\text { Kegiatan Awal } \\
\text { 1. Guru mengkondusifkan } \\
\text { kelas } \\
\text { 2. } \text { Guru membuka pelajaran } \\
\text { dengan mengabsen siswa } \\
\text { 3. } \text { Guru menyampaikan topik } \\
\text { pembelajaran }\end{array}$ & $\begin{array}{c}10 \\
\text { Menit }\end{array}$ & $\begin{array}{l}\text { Kegiatan Awal } \\
\text { 1. } \text { Guru menciptakan kondisi } \\
\text { belajar sebelum mengajar } \\
\text { dimulai. } \\
\text { 2. } \\
\text { Guru menyampaikan } \\
\text { materi pembelajaran }\end{array}$ \\
\hline 50Menit & $\begin{array}{l}\text { Kegiatan inti } \\
\text { 1. Guru membagi kelompok } \\
\text { dan di berikan teks. } \\
\text { 2. Siswa diskusi dalam } \\
\text { kelompok } \\
\text { 3. Siswa diskusi antar } \\
\text { kelompok } \\
\text { 4.Pengarahan terakhir dari } \\
\text { guru } \\
\text { 5.Guru membina suasana } \\
\text { yang responsif di antar siswa } \\
\text { 6.Guru mengemukakan } \\
\text { permasalahan untuk di inkuiri } \\
\text { (ditemukan) } \\
\text { 7. Guru menyuruh siswa } \\
\text { untuk mengajukan } \\
\text { pertanyaan-pertanyaan } \\
\text { kepada siswa } \\
\text { 8. Guru merumuskan }\end{array}$ & $\begin{array}{c}\text { 50Meni } \\
\mathrm{t}\end{array}$ & $\begin{array}{l}\text { Kegiatan Inti } \\
\text { 1. } \text { Guru menjelaskan tentang } \\
\text { unsur kebahsaan teks } \\
\text { cerita fabel } \\
\text { 2. Guru mempersilahkan } \\
\text { siswa untuk bertanya bagi } \\
\text { yang belum mengerti } \\
\text { 3. Memberikan latihan } \\
\text { kepada siswa berupa } \\
\text { menemukan unsur } \\
\text { kebahasaan teks cerita } \\
\text { fabel }\end{array}$ \\
\hline
\end{tabular}




\begin{tabular}{|c|l|l|}
\hline \multirow{3}{*}{ 20Menit } & hipotesis & fabel \\
9. Guru menguji hipotesis & Kegiatan Akhir & 2. Guru dan siswa memberi \\
penguatan dan \\
1. Guru memberikan postes \\
kepada siswa untuk \\
menemukan unsur \\
kebahasaan teks cerita \\
fabel \\
2. Guru mengumpulkan hasil \\
kerja siswa
\end{tabular} \mid

\section{Variabel Penelitian}

Penelitian ini terdiri dari dua variabel yang akan dianalisis baik secara deskripsi maupun analisis statistik. Varibel tersebut dikelompokkan ke dalam variabel yang mempengaruhi (independen) yang dilambangkan $\mathrm{X}_{1}$ dan Variabel yang dipengaruhi (dependen) yang dilambangkan $\mathrm{X}_{2}$. Variabel dalam penelitian ini adalah:

1. Variabel $X_{1} \quad$ : Kemampuan menemukan unsur kebahasaan teks cerita fabel dengan menggunakan model pembelajaran inkuiri

2. Variabel $\mathrm{X}_{2} \quad$ : Kemampuan menemukan unsur kebahasaan teks cerita fabel dengan menggunakan model konvensional
Populasi adalah keseluruhan data yang dianggap refresentif untuk penelitian. Menurut pendapat Sukmadinata (2010: 250). "Populasi adalah penelitian hanya dilakukan terhadapat sekelompok anggota populasi yang mewakili populasi”. Pendapat tersebut diperjelas lagi oleh Sugiyono (2010: 117) yang mengatakan, "Bahwa populasi adalah wilayah generalisasi yang terdiri atas obyek/subyek yang mempunyai kualitas dan karakteristik tertentu yang ditetapkan oleh peneliti untuk dipelajari dan kemudian ditarik kesimpulannya". Populasi dari penelitian ini adalah seluruh siswa kelas VIII SMP Negeri 3 Binjai yang berjumlah 364 siswa yang terdiri dari 9 kelas, dengan rincian sebagi berikut: 
Tabel 3.

Jumlah Siswa Kelas VII SMP Negeri 3 Binjai

\begin{tabular}{|c|c|c|}
\hline No & Kelas & Jumlah \\
\hline 1. & VIII-1 & 36 orang \\
\hline 2. & VIII-2 & 39 orang \\
\hline 3. & VIII-3 & 43 orang \\
\hline 4. & VIII-4 & 44 orang \\
\hline 5. & VIII-5 & 43 orang \\
\hline 6. & VIII-6 & 42 orang \\
\hline 7. & VIII-7 & 40 orang \\
\hline 8. & VIII-8 & 40 orang \\
\hline 9. & VIII-9 & 40 orang \\
\hline & Total Populasi & $\mathbf{3 6 4}$ orang \\
\hline
\end{tabular}

\section{Sampel}

Secara teknik sampel yang wajar untuk dapat diambil dari keseluruan populasi. Menurut Sugiyono (2010: 118), "Bila populasi besar dan peneliti tidak mungkin mempelajari semua yang ada pada populasi, misalnya karena keterbatasan dana, tenaga, dan waktu, penelitian dapat menggunakan sampel yang diambil dari populasi itu". Apa yang dipelajari dari sampel itu, kesimpulannya akan dapat diperlakukan untuk populasi. Untuk itu sampel yang diambil dari populasi harus betul-betul representatif (mewakili).

Penelitian ini, dilakukan pengambilan sampel dengan kelas random atau random sampling. Setiap kelas mempunyai peluang yang sama untuk dipilih menjadi sampel, setiap kelas diberi nomor undian tersebut, untuk kemudian dijadikan sebagai sampel.

\section{Instrumen Penelitian}

Instrumen adalah alat yang digunakan untuk menjaring data penelitian. Untuk memperoleh hasil yang optimal dalam penelitian ini, penelitian menggunakan alat untuk memperoleh data yang akurat. Dalam penelitian ini, peneliti menggunakan tes esai. Tes esai untuk menemukan unsur kebahasaan teks cerita fabel adalah alat ukur yang digunakan 
untuk mengukur aspek-aspek dalam bentuk angka.

\section{HASIL DAN PEMBAHASAN}

Memperoleh data dalam penelitian, maka digunakan instrumen penelitian untuk mengumpulkan data dalam penelitian yang berupa tes kemampuan menemukan unsur kebahasaan teks cerita fabel. Dalam hal ini, akan disajikan data hasil kemampuan siswa dalam menemukan unsur kebahasaan teks cerita fabel. Berdasarkan hasil tes yang telah diperiksa maka nilai yang diperoleh siswa disajikan dalam bentuk tabel.

Tabel 4.

Persentase Nilai Akhir Siswa untuk Kelas Eksperimen

\begin{tabular}{|c|c|c|c|c|}
\hline No & Nilai & Jumlah Sampel & Presentasi & Katagori \\
\hline 1. & $89-99$ & 7 & $19,44 \%$ & Sangat tinggi \\
\hline 2. & $78-88$ & 1 & $2,78 \%$ & tinggi \\
\hline 3. & $67-77$ & 20 & $55,56 \%$ & sedang \\
\hline 4. & $56-66$ & - & - & Kurang \\
\hline 5. & $45-55$ & 8 & $22,22 \%$ & Sangat Kurang \\
\hline
\end{tabular}

Berdasarkan tabel di atas dapat disimpulkan kemampuan menemukan unsur kebahasaan teks cerita fabel dengan menggunakan model Inkuiri adalah sedang, karena 20 orang siswa $(55,56 \%)$ mencapai interval 67-77.

Tabel 5.

Persentase Nilai Akhir Siswa untuk Kelas Kontrol

\begin{tabular}{|c|c|c|c|c|}
\hline No & Nilai & Jumlah Sampel & Presentasi & Katagori \\
\hline 1. & $90-100$ & - & - & Sangat tinggi \\
\hline 2. & $80-89$ & - & - & - \\
\hline 3. & $70-79$ & - & - & - \\
\hline 4. & $59-69$ & - & - & - \\
\hline 5. & $48-58$ & 10 & $25 \%$ & Tinggi \\
\hline 6. & $37-47$ & - & - & Sedang \\
\hline 7. & $26-36$ & 20 & $50 \%$ & Kurang \\
\hline 8. & $15-25$ & 10 & $25 \%$ & Sangat kurang \\
\hline
\end{tabular}


Berdasarkan tabel di atas dapat disimpulkan kemampuan menemukan unsur kebahasaan teks cerita fabel dengan menggunakan model konvensional adalah kurang, karena 20 orang siswa (50\%) mencapai interval 26-36.

Hasil pengujian hipotesis di atas menunjukan pada kelas eksperimen kemampuan siswa menemukan unsur kebahasaan teks cerita fabel dengan model pembelajaran Inkuiri paling banyak berada pada nilai $67-77$ yaitu $55,56 \%$ artinya kemampuan dari sebagian besar siswa kelas eksperimen berada pada tingkat sedang.

Hasil pada kelas kontrol kemampuan menemukan unsur kebahasaan teks cerita fabel dengan model konvensional paling banyak berada pada nilai 26-36 yaitu 50\% artinya kemampuan menemukan unsur kebahasaan teks cerita fabel siswa pada tingkat kurang.

Berdasarkan hasil pengujian hipotesis di atas menunjukkan adanya perbedaan yang nyata kemampuan siswa antara kelas eksperimen dan kelas kontrol dalam kemampuan menemukan unsur kebahasaan teks cerita fabel. Hal ini dibuktikan berdasarkan perhitungan, diketahui pada kelas eksperimen kemampuan siswa dalam menemukan unsur kebahasaan teks cerita fabel mendapat nilai rata-rata 70,78. Sedangkan pada kelas kontrol kemampuan menemukan unsur kebahasaan teks cerita fabel siswa mendapat nilai rata-rata 30,75. Oleh karena itu, hasil pengujian di atas menunjukkan "Ada pengaruh model pembelajaran Inkuiri terhadap Kemampuan menemukan unsur kebahasaan teks cerita fabel oleh Siswa Kelas VIII SMP Negeri 3 Binjai.

\section{PENUTUP}

\section{SIMPULAN}

1. Hasil penelitian kemampuan menemukan unsur kebahasaan teks cerita fabel siswa kelas VIII SMP Negeri 3 Binjai dengan model pembelajaran Inkuiri paling banyak berada pada nilai 67-77 yaitu $55,56 \%$ artinya kemampuan dari sebagian besar siswa kelas eksperimen berada pada tingkat sedang.

2. Hasil penelitian kemampuan menemukan unsur kebahasaan teks cerita fabel siswa kelas VIII SMP Negeri 3 Binjai dengan model konvensional paling banyak berada pada nilai 26-36 yaitu 50\% artinya kemampuan menemukan unsur kebahasaan teks cerita fabel siswa pada tingkat kurang. 
3. Hasil pengujian hipotesis di atas menunjukkan adanya perbedaan yang nyata kemampuan siswa antara kelas eksperimen dan kelas kontrol dalam menemukan unsur kebahasaan teks cerita fabel. Hal ini juga dibuktikan berdasarkan perhitungan yang diketahui pada kelas eksperimen, kemampuan siswa dalam menemukan unsur kebahasaan teks cerita fabel mendapat nilai rata-rata 70,78 . Sedangkan pada kelas kontrol kemampuan menemukan unsur kebahasaan teks cerita fabel siswa mendapat nilai rata-rata 30,75 .

Penelitian menunjukkan bahwa model pembelajaran Inkuiri dapat meningkatkan kemampuan siswa dalam menemukan unsur kebahasaan teks cerita fabel. Hal ini ditandai dengan hargat $_{\text {hitung }}>t_{\text {tabel }} \quad(\mathbf{1 4 , 7 7}>\mathbf{1 , 6 6 6})$ artinya nilai $t_{\text {hitung }}$ lebih besar dari $t_{\text {tabel }}$. Sehingga dapat disimpulkan bahwa model pembelajaran Inkuiri memiliki pengaruh yang nyata terhadap kemampuan siswa dalam menemukan unsur kebahasaan teks cerita fabel.

\section{SARAN}

Saran yang dapat dikemukakan dari hasil penelitian ini adalah:

1. Kepada kepala sekolah disarankan dapat mendukung keprofesiaonalan guru dalam mengajar khususnya mengikut sertakan guru dalam

pelatihan-pelatihan dalam menggunakan model pengajaran yang baik.

2. Kepada guru bidang studi khususnya Bahasa dan Sastra Indonesia agar dapat mempergunakan model Pembelajaran yang sesuai dengan materi yang diajarkan sehingga proses belajar mengajar dapat berjalan dengan aktif dan efektif.

3. Kepada siswa disarankan untuk selalu aktif dalam proses pembelajaran dan mempunyai semangat yang kuat dalam mengikuti kegiatan pembelajaran di kelas.

4. Sebagai bahan masukan bagi mahasiswa (peneliti lain) yang ingin melakukan penelitian dengan memfokus permasalahan yang sama.

\section{DAFTAR PUSTAKA}

Arikunto, Surhasimi.2010. Prosedur penelitian (Satuan Pendekatan Praktik). Jakarta: Rineka Cipta.

Alwi,Hasan dkk.2003.Tata Bahasa Baku Bahasa Indonesia. Jakarta: Balai Pustaka. 
Fionza,Lamudin.2009.Komposisi Bahasa

Indonesia.Jakarta: Diksi Insan Mulia.

Hidayat,Moh Syamsul. 2007. Intisari kata Bahasa Indonesia. Surabaya: Apollo Lestari.

Istarani. 2012.Kumpulan 40 Metode Pembelajaran. Medan: Media Persada. .2012. $58 \quad$ Model Pembelajaran Inovatif. Medan: Media Persada.

Kosasih,E.2003.Ketatabahasaan Dan Kesusastraan.Bandung: Yrama Widya.

Kemendikbud.2014. Bahasa Indonesia Wahana Pengetahuan Kelas VIII SMP. Jakarta: Kemendikbud.

Nazir, Moh. 2011. Metode Penelitian. Bogor : Ghalia Indonesia

Priyatni, Endah Tri.2014. Desain pembelajaran Bahasa Indonesia dalam Kurikulum 2013.

Jakarta: Bumi Aksara.

Roestiyah.2012.Strategi Belajar Mengajar. Jakarta: Rineka Cipta.

Rasyidin Al, dan Nur wahyudin.2011. Teori Belajar dan Pembelajaran. Medan: Perdana Publishing. Shohimin,Aris. 2014. 68 Model Pembelajaran Inovatif dalam Kurikulum 2013. Yogyakarta: Ar-Ruzz Media.
Sudjono, Anas.2010. Pengantar Statistik Pendidikan.Jakarta : PT Rajawali Pers.

Sukmadinata, Nana Syaodih.2010.Metode Penelitian Pendidikan.Bandung: PT Remaja Rosdakarya.

Sugiyono. 2010. Metode Penelitian Pendidikan (Pendekatan Kuantitatif, Kualitatif, dan $R \& D$ ). Bandung: Alfabeta.

Sudjana.2005.Metode Statistika.Bandung : PT Tarsito Bandung.

Saefuddin Asis dan Berdati Ika.2014. Pembelajaran Efektif. Bandung: PT Remaja Rosdakarya 